\title{
Benthic bacterial production in the northern Baltic Sea measured using a modified $\left[{ }^{14} \mathrm{C}\right]$ leucine incorporation method
}

\author{
Susanna Hietanen*, Liisa Tuominen, Jorma Kuparinen \\ Finnish Institute of Marine Research, PO Box 33, 00931 Helsinki, Finland
}

\begin{abstract}
Benthic bacterial production was measured with a modified $\left[{ }^{14} \mathrm{C}\right]$ leucine incorporation method in the northern Baltic Sea in 1996 and 1997. Samples were incubated and TCA extractions were done in microcentrifuge tubes. Unincorporated label was removed by repeated centrifugation. Pellets were suspended in scintillation cocktail and counted as a gel using internal standardisation, a method that gave highly comparable counts with combustion of the sample. Bacterial production varied between 0.15 and $0.8 \mathrm{mg} \mathrm{C} \mathrm{l}^{-1} \mathrm{~h}^{-1}\left(90\right.$ to $\left.350 \mathrm{mg} \mathrm{C} \mathrm{m}^{-2} \mathrm{~d}^{-1}\right)$. The highest production was found at Stn GF2 in the Gulf of Finland and the lowest in the northern Baltic Proper. Bacterial growth rates were 0.07 to $0.84 \mathrm{~d}^{-1}$. Comparison of these results with published data from sedimentation trap measurements suggests that only a part of the benthic bacterial $\mathrm{C}$ demand can be explained by sedimentation.
\end{abstract}

KEY WORDS: Bacterial production - Sediment - Leucine $\cdot$ Baltic Sea

\section{INTRODUCTION}

Using leucine incorporation for measuring bacterial production has recently received increasing interest in sediment studies. This is partly explained by the controversy with the thymidine method, the previous method of choice (see review by Robarts \& Zohary 1993). Leucine incorporation, which measures bacterial protein synthesis, gives a direct measurement of bacterial biomass change (or carbon production) because ca $60 \%$ of bacterial dry mass consists of proteins (Simon \& Azam 1989). The ratio of cellular protein to carbon and the molar proportion of leucine compared to other amino acids has been found to be rather constant in natural bacterioplankton assemblages (Simon \& Azam 1989). Therefore, conversion factors needed to calculate the results are quite constant, which makes the method attractive.

Various techniques have been used to study leucine incorporation in sediments (Table 1). Combustion is

•E-mail: susanna.hietanen@fimr.fi the only method to produce a homogenous and transparent sample for scintillation counting from a sample containing sediment particles. However, oxidizers are not very common, especially not onboard research vessels. Consequently, samples cannot be counted immediately after incubation, e.g. onboard a research vessel or at a field station, which makes on-site methodological adjustment (e.g. isotope concentration, incubation time) impossible. However, portable scintillation counters can be used on research vessels or at field stations that are normally not equipped with a scintillation counter.

The Baltic Sea is a brackish water area characterized by significant anthropogenic nutrient loading (Wulff et al. 1990). Although the (micro) biology of the Baltic Sea plankton has been widely studied (see e.g. Kuparinen \& Kuosa 1993), the microbiological aspects of its sediment have remained less studied (but see Meyer-Reil 1986 and references therein, Piker \& Reichardt 1991). In this study, we measured bacterial production in the sediments of the open areas of the northern Baltic Sea. Bacterial production was measured using a modified $\left[{ }^{14} \mathrm{C}\right]$ leucine incorporation method in which centrifuga- 
Table 1. Methods used to study leucine incorporation in sediments

\begin{tabular}{|c|c|}
\hline Method & Source \\
\hline \multicolumn{2}{|l|}{$\begin{array}{l}\text { Macromolecules extracted from sediment with } \mathrm{NaOH}_{t} \\
\text { EDTA and SDS followed by }\end{array}$} \\
\hline (a) precipitation by TCA and solubilization of protein by hot $\mathrm{NaOH}$ & Meyer-Reil \& Charfreitag (1991), Marxsen (1996) \\
\hline (c) direct measurement & Epstein (1997) \\
\hline $\begin{array}{l}\text { Bacterial cells lysed with } \mathrm{NaOH} \text {, after which TCA was added, } \\
\text { samples heated to } 95^{\circ} \mathrm{C} \text {, cooled in ice, and filtered. } \\
\text { The precipitated proteins solubilized in hot SDS }\end{array}$ & Moran \& Hodson (1992) \\
\hline $\begin{array}{l}\text { Samples washed with ethanol followed by precipitation of DNA and } \\
\text { protein by ice-cold TCA and solubilization of protein by hot } \mathrm{NaOH}\end{array}$ & Moriarty et al. (1991), van Duyl \& Kop (1994) \\
\hline Samples washed with ethanol and the washed pellet combusted & $\begin{array}{l}\text { Meyer-Reil (1986), Tuominen \& Kairesalo (1992), } \\
\text { Kairesalo et al. (1994), Tuominen (1995), } \\
\text { Tuominen et al. (1996) }\end{array}$ \\
\hline
\end{tabular}

tion was used for macromolecule collection. This kind of method has previously been applied for water samples (Smith \& Azam 1992) but not for sediment. The radioactivity of the sediment pellet was measured as a gel using internal standardisation in the scintillation counting, and was compared with the combustion method.

\section{MATERIAL AND METHODS}

Sediment samples were collected with a Gemini twin corer (inner diameter of the cores $80 \mathrm{~mm}$ ) from the northern Baltic Sea during cruises onboard the RV 'Aranda' and RV 'Alkor' in 1996 and 1997 (Fig. 1). Only the top $1 \mathrm{~cm}$ was used in the incubations, except in the vertical distribution experiment (see below).

The routine procedure for measuring leucine incorporation was as follows: small amounts (normally $100 \mu \mathrm{l}$, see below) of sediment slurry were mixed in $1.5 \mathrm{ml}$ microcentrifuge tubes with increasing concentrations of $\left[{ }^{14} \mathrm{C}\right.$ leucine $\left(11.1\right.$ to $11.3 \mathrm{GBq} \mathrm{mmol}^{-1}$, Amersham, diluted with filtered seawater). The incubation volume was adjusted to $500 \mu$ with filtered (0.2 $\mathrm{mm}$ pore-size, Minisart, Sartorius) near-bottom seawater. The $\left[{ }^{14} \mathrm{C}\right]$ leucine additions to determine the saturation level varied in the beginning between 0.1 and $10.8 \mu \mathrm{M}$ and later between ca 0.3 and $4 \mu \mathrm{M}$. No carrier was used in any incubations. Control samples (the results of which were subtracted before calculating the production rates) were prepared by adding the isotope into microcentrifuge tubes containing the sediment slurry plus $1 \mathrm{ml}$ of ice-cold $10 \%$ TCA. Samples were incubated in the dark at in situ temperature. The optimal incubation time was determined on every cruise, except August 1996, by incubating a series of samples for 15 to $230 \mathrm{~min}$ (times varied from cruise to cruise). Incubation was terminated by adding $1 \mathrm{ml}$ of ice-cold 10\% TCA. Unincorporated isotope was removed from samples and macromolecules were collected by repeated centrifugation $(10 \mathrm{~min} 10000 \times \mathrm{g}$ at $4^{\circ} \mathrm{C}$ ), once using 70 to $80 \%$ ethanol and twice using ice-cold $10 \%$ TCA. Washing with ethanol removed most of the pigments that lowered the scintillation counting efficiency.

After the washings, the caps of the tubes were removed (caps contained only traces of radioactivity) and the tubes were cut into 2 pieces and put into glass scintillation vials. Pellets were suspended in scintillation cocktail (Instagel or Instagel Plus, Packard) until no visible pellets were observed in the bottom of the microcentrifuge tubes. Samples were counted as gel

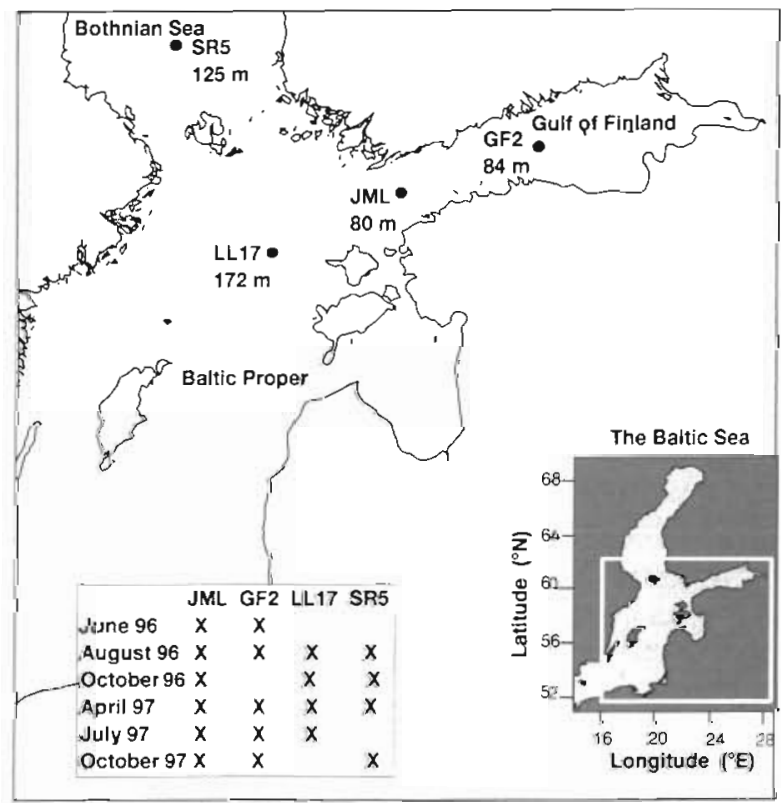

Fig. 1. Sampling stations and times 
including the pieces of microcentrifuge tubes $\left(1 / 3 \mathrm{H}_{2} \mathrm{O}\right.$, $2 / 3$ Instagel according to manufacturer's recommendations) in a liquid scintillation counter. For sediment samples, the gel matrix is important since otherwise the sediment particles would settle to the bottom of the vial and distort the counting geometry. Since ${ }^{14} \mathrm{C}$ was used instead of ${ }^{3} \mathrm{H}$, the possible effect of the small sediment particles suspended in the scintillation cocktail on the counting geometry was minor (cf. Amon \& Benner 1998, Robarts 1998). The counts per minute (cpm) were converted to disintegrations per minute (dpm) using the counting efficiency measured by internal standardisation in which a standard capsule (ca $100000 \mathrm{dpm}$, Wallac) was added to 3 control samples which were then re-counted. This gel method was tested against the combustion method (Tuominen 1995) in which the samples were dried at $60^{\circ} \mathrm{C}$ after similar washings using centrifugation and then combusted at $900^{\circ} \mathrm{C}$ (Junitek Oxidizer) prior to scintillation counting.

The results obtained were converted to bacterial carbon production (BCP, g) using the equation of Simon \& Azam (1989):

$$
\mathrm{BCP}=\text { leucine }_{\mathrm{nc}} \times(100 / 7.3) \times 131.2 \times 0.86
$$

where leucine $_{1 \mathrm{nc}}=$ moles of leucine incorporated, $7.3=$ mol $\%$ of leucine in protein, $131.2=$ formula weight of leucine, and $0.86=$ conversion of a gram of protein produced to a gram of carbon.

Time series incubations using different amounts of sediment $(50$ to $400 \mu l)$ were carried out to test the effect of the volume of sediment used in the incubations. The possible effect of the filtered, near-bottom seawater (used to slurry the sediment and to adjust the incubation volume to $500 \mu \mathrm{ll}$ ) was checked by incubating samples with different amounts of seawater (0 to $400 \mu \mathrm{ll}$ ).

In October 1997, an experiment was performed to study the vertical distribution of bacterial production. At Stns JML and GF2, bacterial production was measured from the 1 to $2 \mathrm{~cm}$ sediment layer in addition to the 0 to $1 \mathrm{~cm}$ top layer. At Stn SR5, the layers 0-1, 1-2 and $2-3 \mathrm{~cm}$ were analyzed due to a visually deeper oxidized layer.

Bacterial abundance in the sediment was counted from DAPI-stained samples using an epifluorescence microscope (excitation wave length $365 \mathrm{~nm}$; Porter \& Feig 1980). Samples were diluted 500 times, and stained at a DAPI concentration of $10 \mu \mathrm{g} \mathrm{ml}^{-1}$ for at least $20 \mathrm{~min}$.

Statistical analysis. The gel method was compared to the combustion method by calculating regression equations with the 'new' gel method being the independent variable and the 'old' combustion method the dependent variable. If the methods gave $1: 1$ results, the constant of the regression equation should be zero and the coefficient one. In addition, linear correlations were calculated.

\section{RESULTS AND DISCUSSION}

\section{Methodology}

The linear correlation between leucine incorporation in samples measured as a gel and combusted samples was high. In 6 cases out of 8 , the constant of the regression equation did not significantly differ from zero, and in 5 cases the value 1 was within the $95 \%$ confidence interval of the coefficient (Fig. 2). The gel method thus proved to be accurate for the northern Baltic mud sediments. It speeds up the analytical procedure and facilitates the counting of samples where an oxidizer is not available. The counting efficiency was almost constant within each station during each sampling occasion (coefficient of variation 0.2 to $6.4 \%$ ), so the use of an internal standard for each sampling site provided a reliable dpm conversion. The counting efficiency varied, however, between the sampling stations and seasonally within stations (from 46 to $87 \%$ ).

The saturation level at the different stations and sampling times varied between 2.5 and $3 \mu \mathrm{M}$ of leucine (Fig. 3). This is much lower than $14 \mu \mathrm{M}$ observed for 4 different lake sediments (Tuominen 1995) or $20 \mu \mathrm{M}$ for a stream-bed sediment (Marxsen 1996). On the other hand, in a marine sediment a saturation level as low as $0.5 \mu \mathrm{M}$ has been found (Moriarty et al. 1991). Obviously the adaptation by bacteria to the scarcity of easily degradable organic matter in deep (in this study 80 to $172 \mathrm{~m}$ ) marine sediments as compared to lake and river sediments causes the lower saturation level. Time series incubations showed that the incorporation of $\left[{ }^{14} \mathrm{C}\right]$ leucine was linear for at least $230 \mathrm{~min}$ (Fig. 4).

The amount of sediment used in the incubations did not affect the leucine incorporation rate during the 45 to $140 \mathrm{~min}$ used in routine incubations (Fig. 4). The decision to use $100 \mu \mathrm{l}$ in routine incubations was based on practical sample handling. This amount can be pipetted reliably using an adjustable dispenser (Finnpipette Stepper, Labsystems). Smaller amounts of sediment were difficult to measure accurately and larger amounts increased the variance of the counting efficiency. Different amounts of near-bottom water to make a slurry had no effect on the leucine incorporation rate (data not shown).

\section{Field observations}

Bacterial production varied between 0.15 and $0.8 \mathrm{mg}$ $\mathrm{C}^{-1} \mathrm{~h}^{-1}$ at the 4 stations (Table 2). The highest pro- 

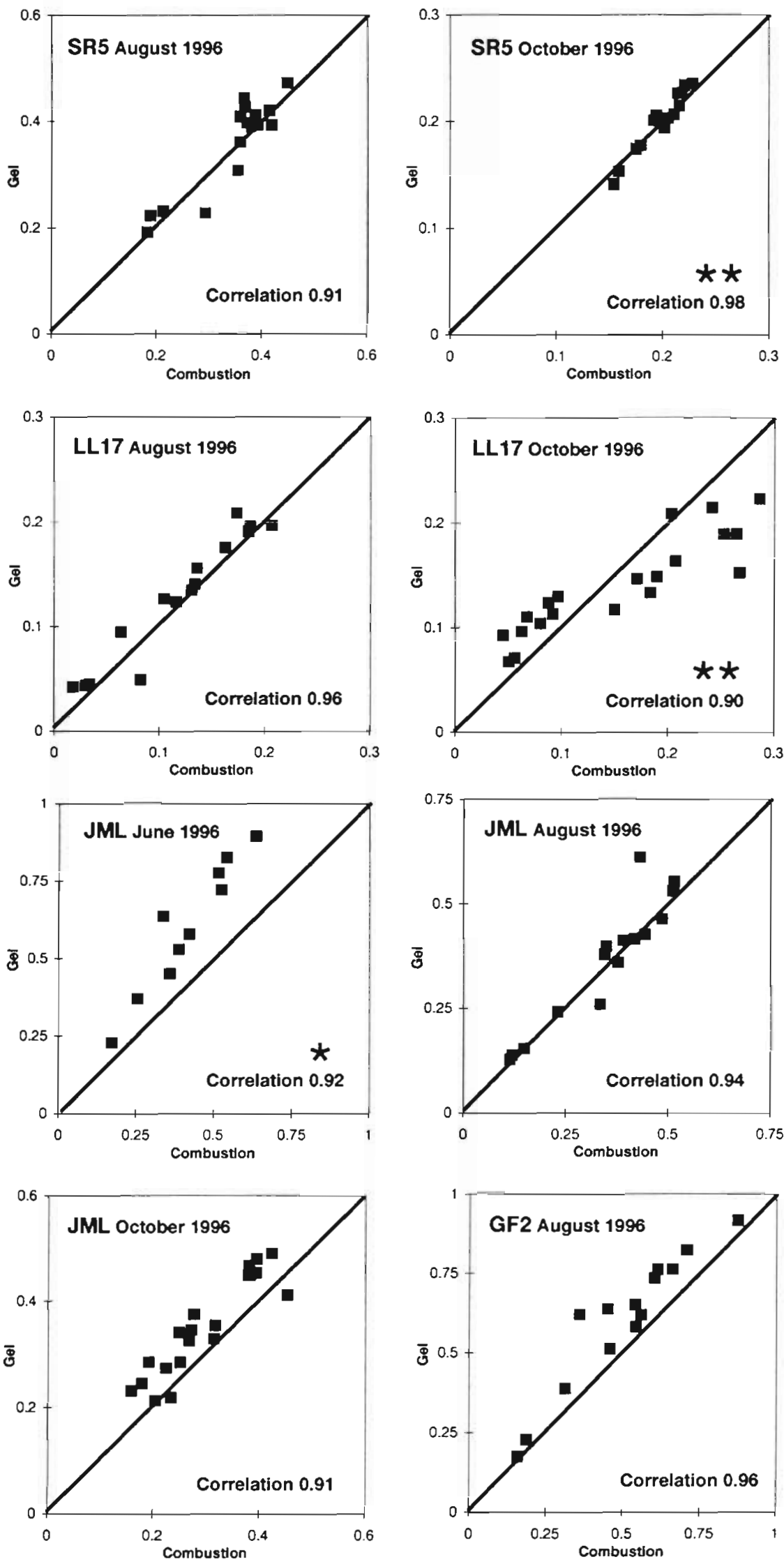
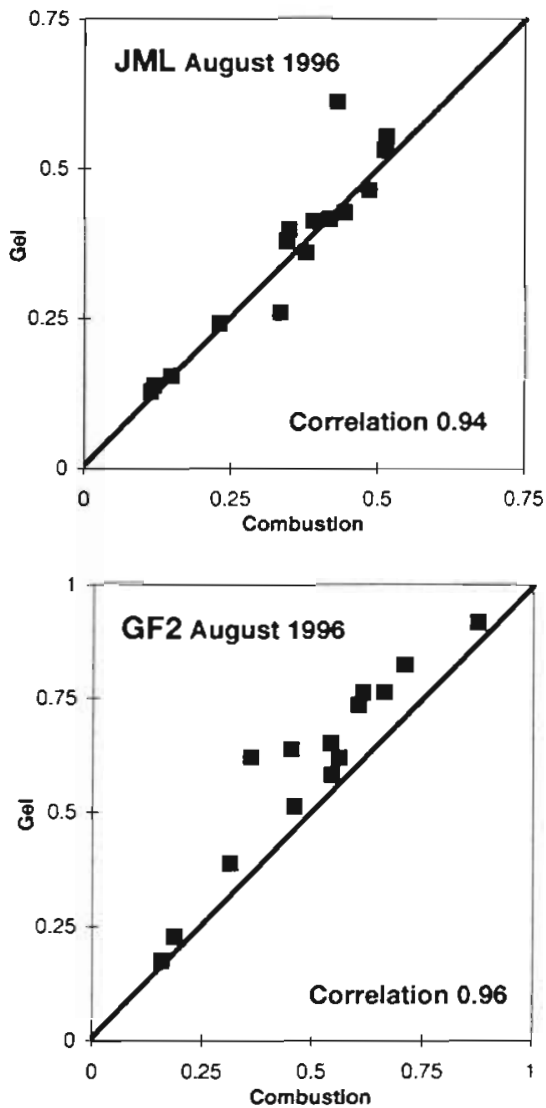

duction was found at Stn GF2 in the Gulf of Finland, which is the most eutrophicated area in the present study (Wulff et al. 1990). This sediment area also shows the highest denitrification activity (Tuominen et al. 1998). The present bacterial production rates are comparable with values obtained from the North Sea (van Duyl \& Kop 1994) if only stations deeper than $40 \mathrm{~m}$ (their Stns 3 to 11) are included. The shallower stations in the North Sea showed higher rates. Moriarty et al. (1991) measured bacterial production from the East Australian continental margin (depths 149 and $200 \mathrm{~m}$ ) and found values which are very comparable with the rates from our deepest stations, SR5 and LL17. However, considerably higher rates (up to $5.7 \mathrm{mg} \mathrm{C} \mathrm{h}^{-1} \mathrm{l}^{-1}$ ) have been measured from eutrophic freshwater sediments (depths 1 to $30 \mathrm{~m}$; Moran \& Hodson 1992, Tuominen 1995).

When comparing bacterial production rates from different studies, one has to be aware of the use of different conversion factors. In the present study (and in Tuominen 1995), the theoretical conversion factor of $1.5 \mathrm{~kg} \mathrm{C} \mathrm{mol}{ }^{-1}$ leucine taken up (Simon \& Azam 1989) was used. Since the calculations were carried out for results obtained at the saturating concentration of leucine, no isotope dilution factor was used. In some cases, however, saturation was not straightforward. Van Duyl \& Kop (1994) used the same conversion factor in addition to their determined isotope dilution. In contrast to this, Moran \& Hodson (1992) used a conversion factor of $8.6 \mathrm{~kg} \mathrm{C} \mathrm{mol}^{-1}$, which they empirically determined for water samples. Bjørnsen \& Kuparinen (1991) obtained an empirical conversion factor of $3.0 \mathrm{~kg} \mathrm{C} \mathrm{mol} \mathrm{kg}^{-1}$ of leucine incorporated

Fig. 2. Correlation between the combustion and the gel method (bacterial production in mg $\mathrm{C}^{-1} \mathrm{~h}^{-1}$; for methods see text). Line represents $1: 1$ plot. $\star \star \star=$ constant of the regression equation significantly different from zero $(p<0.05)$ and value 1 not within the $95 \%$ confidence interval of the coefficient (see 'Material and methods'). * = value 1 not within the $95 \%$ confidence interval of the coefficient 

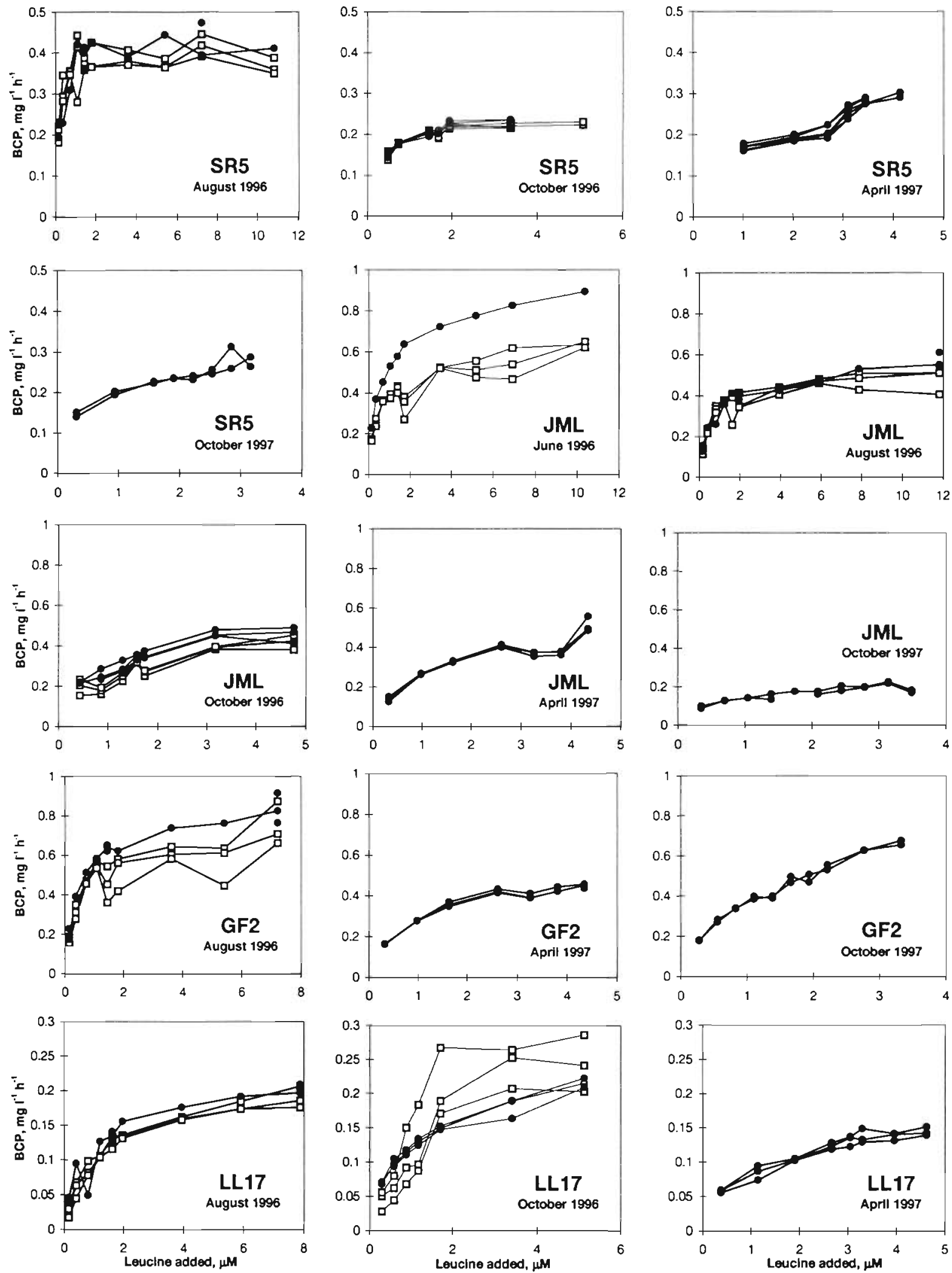

Fig. 3. Leucine incorporation versus added leucine concentration. Incorporation is given as bacterial carbon production (BCP) calculated using the conversion factor $1546 \mathrm{~g} \mathrm{C} \mathrm{mol}^{-1}$ leucine incorporated. $\square$ : combusted samples; : gel method. Unconnected data points refer to extra replicates. Note different scales for different stations 


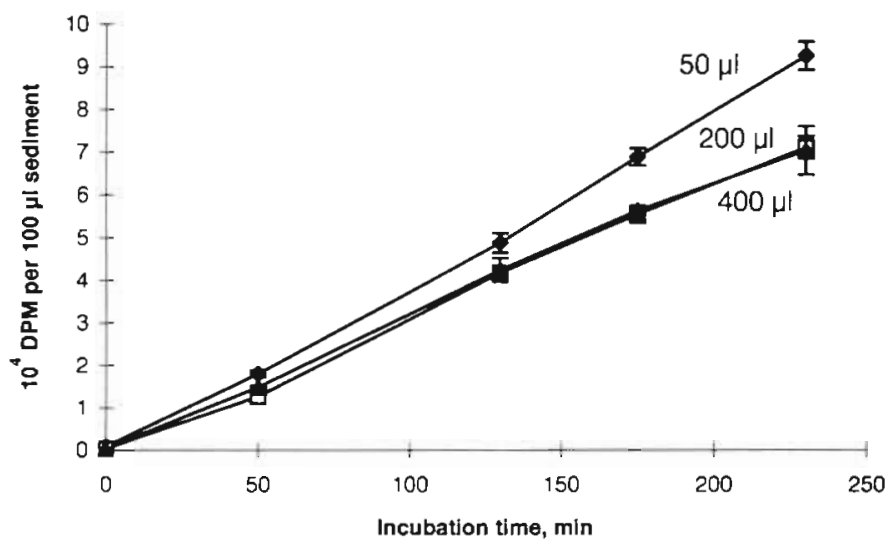

Fig. 4. Stn JML, July 1997. Time series incubations for different amounts of sediment used. Error bars show SD when larger than the symbol size. Results standardised to $100 \mu \mathrm{l}$ of sediment

for water samples from the Southern Ocean. Our conversion factor may be underestimated since even if 'saturation' was achieved some isotope dilution is possible, and the true production may be as much as 2 times higher than estimated (Bjørnsen \& Kuparinen 1991, Moran \& Hodson 1992, van Duyl \& Kop 1994).

At Stns GF2 and JML in the Gulf of Finland, 55 and $68 \%$, respectively, of the measured bacterial production occurred in the top $1 \mathrm{~cm}$ of sediment (Fig. 5). In the Bothnian Sea (Stn SR5), where the oxygenated layer is deeper, the top $3 \mathrm{~cm}$ showed almost identical bacterial production (Fig. 5). However, it must be noted that bacterial production was not measured deeper than 2 or $3 \mathrm{~cm}$. Moriarty et al. (1991) calculated from thymidine incorporation that 20 to $30 \%$ of bacterial production was in the top $1 \mathrm{~cm}, 60$ to $70 \%$ in the top $2 \mathrm{~cm}$ and nearly $100 \%$ in the top $10 \mathrm{~cm}$ in the continental margin of eastern Australia.

Bacterial abundance varied between 0.32 and $2.23 \times$ $10^{9}$ cells $\mathrm{ml}^{-1}$ (Table 3 ). In the oligotrophic Bothnian Sea (Stn SR5), the abundance was slightly lower than

Table 2. Bacterial production in the sediments of the northern Baltic Sea

\begin{tabular}{|c|c|c|c|}
\hline Stn & $\begin{array}{l}\operatorname{mg~C~} 1^{-1} \mathrm{~h}^{-1} \\
(\text { in top } 1 \mathrm{~cm})\end{array}$ & $\begin{array}{l}\text { Bacterial production } \\
\mathrm{mg} \mathrm{C} \mathrm{m}^{-2} \mathrm{~d}^{-1} \\
\text { (in top } 1 \mathrm{~cm})\end{array}$ & $\begin{array}{l}\underset{\operatorname{mg~C~m} \mathrm{C}^{-2} \mathrm{~d}^{-1}}{(\text { in top } 3 \mathrm{~cm})^{\mathrm{d}}}\end{array}$ \\
\hline SR5 & $0.2-0.4$ & $48-96$ & $160-320$ \\
\hline JML & $0.25-0.8$ & $60-192$ & $88-282$ \\
\hline GF2 & $0.4-0.8$ & $96-192$ & $175-349$ \\
\hline LL1.7 & $0.15-0.25$ & $36-60$ & $-b$ \\
\hline
\end{tabular}

in the Gulf of Finland. In the 1 to $2 \mathrm{~cm}$ layer the abundance was higher than in the 0 to $1 \mathrm{~cm}$ layer. This is obviously caused by the dilution effect of water in the topmost $\mathrm{cm}$ of sediment. Previous determinations of bacterial abundance in the Baltic Sea sediments are available from Stn SR5, where Mohammadi et al. (1993) counted 0.56 to $1.3 \times 10^{9}$ cells $\mathrm{ml}^{-1}$ using acridine orange staining. Bacterial growth rates varied between 0.07 and $0.84 \mathrm{~d}^{-1}$ (Table 3; leucine incorporation converted to cell production using the theoretical

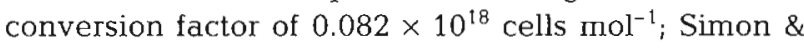
Azam 1989, Kirchman 1992). Previously published growth rates for sediment bacteria vary from 0.01 to $0.004 \mathrm{~d}^{-1}$ (Lake Vallentunasjön, depth $2.5 \mathrm{~m}$, at $+4^{\circ} \mathrm{C}$; Bell \& Ahlgren 1987) to $0.14-0.6 \mathrm{~d}^{-1}$ (East Australian continental margin, depth 140 and $200 \mathrm{~m}$; Moriarty et al. 1991). The higher range of variation in the growth rates (12 times from the lowest to the highest) compared to bacterial abundance ( 7 times) in the present study suggests that bacterial abundance in the sediment varies less than the proportion of active bacteria within the bacterial population.

The overall variation of bacterial production in the sediment was much less than in the water column, where variation in orders of magnitude is typical 0 to $100 \mathrm{mg} \mathrm{C} \mathrm{m} \mathrm{Cd}^{-1}$; Kuparinen \& Kuosa 1993). This is caused by the more stable conditions (temperature, availability of organic matter) compared to the water. Since the sediment was sampled only 3 times a year, it is possible that peaks have been missed. However, in laboratory experiments where settling algae have been added to sediment cores, we have found only moderate response in sediment bacterial production (maximum 5-fold; Tuominen et al. 1999 unpubl.).

If a growth yield of $40 \%$ is assumed as determined for sediment bacteria by Bell \& Ahlgren (1987), sediment bacteria were calculated to require 0.4 to $0.8 \mathrm{~g} \mathrm{C}$

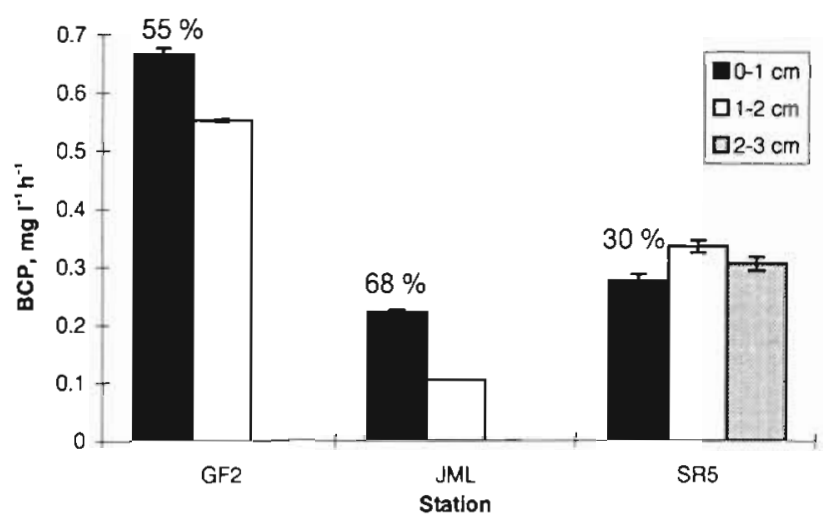

Fig. 5. October 1997. Depth distribution of bacterial carbon production in sediment. Error bars show range of 2 replicates. The proportion of $\mathrm{BCP}$ in the top $1 \mathrm{~cm}$ is shown by percentages 
Table 3. Bacterial abundance $\left(10^{9}\right.$ cells $\left.\mathrm{ml}^{-1}\right)$ and growth rate $\left(\mathrm{d}^{-3}\right)$ in the surface sediments $(0$ to $1 \mathrm{~cm}$ unless otherwise stated) of the northern Baltic Sea

\begin{tabular}{|c|c|c|c|c|c|c|c|c|c|}
\hline & & \multicolumn{8}{|c|}{ Station } \\
\hline & & \multicolumn{2}{|c|}{ SR5 } & \multicolumn{2}{|c|}{ JML } & \multicolumn{2}{|c|}{ GF2 } & \multicolumn{2}{|c|}{ LL17 } \\
\hline & & Abundance & Growth rate & Abundance & Growth rate & Abundance & Growth rate & Abundance & Growth rate \\
\hline Jun 1996 & & & & 1.13 & 0.66 & 0.98 & 0.84 & & \\
\hline Aug 1996 & & 0.72 & 0.69 & 1.37 & 0.36 & 1.35 & 0.53 & & \\
\hline Oct 1996 & & 0.32 & 0.88 & 1.38 & 0.40 & 1.27 & 0.35 & & \\
\hline Apr 1997 & & 0.87 & 0.39 & 0.94 & 0.59 & 1.14 & 0.47 & 0.84 & 0.21 \\
\hline Oct 1997 & $0-1 \mathrm{~cm}$ & 1.29 & 0.23 & 1.29 & 0.17 & 1.46 & 0.55 & & \\
\hline & $1-2 \mathrm{~cm}$ & 1.56 & 0.27 & 2.01 & 0.07 & 2.23 & 0.32 & & \\
\hline & $2-3 \mathrm{~cm}$ & 0.67 & 0.58 & & & & & & \\
\hline
\end{tabular}

$\mathrm{m}^{-2} \mathrm{~d}^{-1}$ in the Bothnian Sea (Stn SR5) and 0.4 to $0.9 \mathrm{~g} \mathrm{C}$ $\mathrm{m}^{-2} \mathrm{~d}^{-1}$ in the Gulf of Finland (Stn GF2). On the contrary, measured sedimentation using sediment traps averaged only $0.077 \mathrm{~g} \mathrm{C} \mathrm{m}^{-2} \mathrm{~d}^{-1}$ at Stn SR5 (Lehtonen \& Andersin 1998) and 0.1 to $0.2 \mathrm{~g} \mathrm{C} \mathrm{m}^{-2} \mathrm{~d}^{-1}$ at Stn GF2 (Kankaanpää et al. 1997, Leivuori \& Vallius 1998). It appears, therefore, that sediment trap measurements underestimate the total available $\mathrm{C}$ for the benthic ecosystem, a conclusion drawn also by Lehtonen \& Andersin (1998). There are 4 possible reasons for this: (1) Sediment trap measurements give too low an estimate of the amount of settling material. (2) Horizontal carbon flow near the sediment surface is important. (3) Bacteria utilize partly old, recycled carbon in the sediment. (4) Bacterial C demand was overestimated, which is, however, not probable since our conversion factor may be an underestimate and the growth yield an overestimate leading to even higher $\mathrm{C}$ demand. Growth yields as low as 10 to $25 \%$ have been determined for planktonic bacteria (del Giorgio et al. 1997). In conclusion, however, since the bacterial production results were of the same order of magnitude as the sedimentation data, it seems that the leucine incorporation technique to measure benthic bacterial production is an ecologically valid and meaningful assay.

Acknowledgements. We are indebted to the crews of the research vessels for help in the field, and to Prof. Imhoff and Dr Gocke for the opportunity to join the RV 'Alkor' cruise. We thank Antti Uusi-Rauva and Kaj-Roger Hurme (Isotope Section, University of Helsinki, Faculty of Agriculture and Forestry) for help with the Junitek Oxidizer. Markit Likolammi is acknowledged for counting the bacteria. This study was partly funded by the EU (BA.SYS project) through MAST programme (contract MAS3-CT96-0058).

\section{LITERATURE CITED}

Amon RMW, Benner R (1998) Seasonal patterns of bacterial abundance and production in the Mississippi River plume and their importance for the fate of enhanced primary production. Microb Ecol 35:289-300
Bell RT, Ahlgren I (1987) Thymidine incorporation and microbial respiration in the surface sediment of a hypereutrophic lake. Limnol Oceanogr 32:476-482

Bjørnsen PK, Kuparinen J (1991) Determination of bacterioplankton biomass, net production and growth efficiency in the Southern Ocean. Mar Ecol Prog Ser 71:185-194

del Giorgio P, Cole JJ, Cimbleris A (1997) Respiration rates in bacteria exceed phytoplankton production in unproductive aquatic systems. Nature 385:148-151

Epstein SS (1997) Microbial food webs in marine sediments. I. Trophic interactions and grazing rates in two tidal flat communities. Microb Ecol 34:188-198

Kairesalo T, Tuominen L, Hartikainen H, Rankinen K (1994) The role of bacteria in the nutrient exchange between sediment and water in a flow-through system. Microb Ecol 29: $129-144$

Kankaanpää H, Korhonen M, Heiskanen AS, Suortti AM (1997) Seasonal sedimentation of organic matter and contaminants in the Gulf of Finland. Boreal Environ Res 2: $257-274$

Kirchman DL (1992) Incorporation of thymidine and leucine in the subarctic Pacific: application to estimating bacterial production. Mar Ecol Prog Ser 82:301-309

Kuparinen J, Kuosa H (1993) Autotrophic and heterotrophic picoplankton in the Baltic Sea. Adv Mar Biol 29:73-128

Lehtonen KK, Andersin AB (1998) Population dynamics, response to sedimentation and role in benthic metabolism of the amphipod Monoporeia affinis in an open-sea area of the northern Baltic Sea. Mar Ecol Prog Ser 168:71-85

Leivuori M, Vallius $H$ (1998) A case study of seasonal variation in the chemical composition of accumulating suspended sediments in the central Gulf of Finland. Chemosphere 36:2417-2435

Marxsen J (1996) Measurement of bacterial production in stream-bed sediments via leucine incorporation. FEMS Microbiol Ecol 21:313-325

Meyer-Reil LA (1986) Measurement of hydrolytic activity and incorporation of dissolved organic substrates by microorganisms in marine sediments. Mar Ecol Prog Ser 31. 143-149

Meyer-Reil LA, Charfreitag O (1991) Observations on the microbial incorporation of thymidine and leucine in marine sediments. Kiel Meeresforsch Sonderh 8:117-120

Mohammadi M, Karjala L, Kuparinen J (1993) Number, biovolume and biomass of bacteria in the mud sediment of the Bothnian Sea. Aqua Fenn 23:201-208

Moran MA, Hodson RE (1992) Contributions of three subsystems of a freshwater marsh to total bacterial secondary productivity. Microb Ecol 24:161-170

Moriarty DJW, Skyring GW, O'Brien GW, Heggie DT (1991) 
Heterotrophic bacterial activity and growth rates in sediments of the continental margin of eastern Australia Deep-Sea Res 38:693-712

Piker L, Reichardt W (1991) Do sulfate-reducing bacteria respond to thymidine incorporation assays in marine sediments? Kiel Meeresforsch Sonderh 8:102-106

Porter KG, Feig YS (1980) The use of DAPI for identifying and counting aquatic microflora. Limnol Oceanogr 25:943-948

Robarts RD (1998) Incorporation of radioactive precursors into macromolecules as measures of bacterial growth: problems and pitfalls. In: Cooksey KE (ed) Molecular approaches to the study of the ocean. Chapman \& Hall, London, p 471-486

Robarts RD, Zohary T (1993) Fact or fiction - bacterial growth rates and production as determined by $\left[\right.$ methyl $\left.{ }^{3} \mathrm{H}\right]$-thymidine? Adv Microb Ecol 13:371-425

Simon M, Azam F (1989) Protein content and protein synthesis rates of planktonic marine bacteria. Mar Ecol Prog Ser $51: 201-213$

Smith DC, Azam F (1992) A simple, economical method for measuring bacterial protein synthesis rates in seawater using ${ }^{3} \mathrm{H}$-leucine. Mar Microb Food Webs 6:107-114

Tibbles BJ, Davis CL, Harris JM, Lucas MI (1992) Estimates of bacterial productivity in marine sediments and water from

Editorial responsibility: David Karl,

Honolulu, Hawaii, USA a temperate saltmarsh lagoon. Microb Ecol 23:195-209

Tuominen L (1995) Comparison of leucine uptake methods and a thymidine incorporation method for measuring bacterial activity in sediment. J Microb Methods 24:125-134

Tuominen L, Kairesalo T (1992) A method for measuring the uptake of thymidine and leucine in sediment. Aqua Fenn $22: 43-48$

Tuominen L, Kairesalo T, Hartikainen H, Tallberg P (1996) Nutrient fluxes and microbial activity in sediment enriched with settled seston. Hydrobiologia 335:19-31

Tuominen L, Heinänen A, Kuparinen J, Nielsen LP (1998) Spatial and temporal variability of denitrification in the sediments of the northern Baltic Proper. Mar Ecol Prog Ser 172:13-24

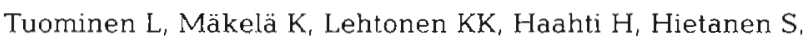
Kuparinen J (1999) Nutrient fluxes, pore water profiles and denitrification in sediment influenced by algal sedimentation and bioturbation by Monoporeia affinis. Estuar Coast Shelf Sci 49:83-97

van Duyl FC, Kop AJ (1994) Bacterial production in North Sea sediments: clues to seasonal and spatial variations. Mar Biol 120:323-337

Wuiff $F$, Stigebrandt A, Rahm L (1990) Nutrient dynamics of the Baltic Sea. Ambio 19:126-133

Submitted: May 12, 1998, Accepted: June 2, 1999 Proofs received from author(s): October 22, 1999 